\title{
PRESENT ABSENCE: MEMORY AND \\ NARRATIVE IN Los recuerdos del porvenir
}

\section{Amalia Gladhart}

University of Oregon

Elena Garro's Los recuerdos del porvenir (1963) describes a world in which memory is at once paramount and unreliable. The novel's collective narrator (the town of Ixtepec) recalls the past while perched on a "piedra aparente," a seeming stone that is in fact the petrified body of Isabel Moncada, one of the novel's two female protagonists. Isabel's stone body grounds the narrative at the same time that its presence undermines the narrator's authority. Garro's novel offers a powerful evocation of both the attraction and the difficulty of memory as that which is past and at the same time present. As the narrator muses at the outset, "Yo sólo soy memoria y la memoria que de mí se tenga" (9). The complex constitution of the narrator, the roles of Isabel Moncada and Julia Andrade, and the unstable nature of memory are brought together in the transformation of Isabel's body into the double figure of memory and forgetting that is at the heart of the novel's narrative structure. At once visible and invisible, the stone body of Isabel becomes an inscribed monument, a double figure of presence and absence. That doubling is at the core of Latin American memory narratives such as Albalucía Ángel's Estaba la pájara pinta sentada en el verde limón (Colombia, 1975), Alicia Yánez Cossío's La cofradía del mullo del vestido de la Virgen Pipona (Ecuador, 1985), and Marta Traba's Conversación al sur (Argentina, 1981), many of which situate memory at the juncture of embodiment and disembodiment. In all of these narratives, the body is a problematic repository for the past because of its fragility and vulnerability. Individual human memory requires a living body for its continuation, yet as individual or private experiences are assem- 
bled into a collective memory, a shared link to the past is asserted even as that individual connection may be lost. Isabel becomes a marker of a collective past and in the process, her individual memories are obscured, so that while the novel offers tantalizing hints as to her motivations, it retains an uncertainty at its center.

This article will highlight the undecidability at the heart of Garro's novel, the link between presence and absence that makes the narrative possible and at the same time undermines the apparent ground-memory-on which it rests. My analysis differs from earlier studies of the novel in its emphasis on ambiguity, on the emptiness of Isabel-as-monument, and on the importance of the body as the apparent foundation or form of that monument. The representation of memory in the novel is superficially straightforward yet deceptively complex. What has often been missed is that it is precisely the unresolved tension between presence and absence that shapes the novel's approach to memory. The difficulty of fully determining Isabel's motives is symptomatic of the problems of memory and narrative presented by the novel. The novel closes with the inscription, in stone, of an "explanation" of the novel's events and of Isabel's betrayal of her family and community. The stone makes visible the contested words that Juan Cariño, the town's "best madman," has spent much of his time attempting to corral and return to the dictionary. It also provides a definition of unacceptable feminine desire. The inscribed stone makes the female body legible. This readable body, in turn, makes memory possible. The voice behind the inscription, however, is that of a marginalized medicine woman or witch. The narrator rests on the empty yet apparently solid remains of Isabel, but although the plaque placed by Gregoria offers a supposedly unambiguous reading of that body, the novel leading up to those final words does much to undermine the authority of the inscription. Isabel remains ambiguous because the alleged clarity of collective memory is a mirage, because in the move from individual (embodied) memory to collective (disembodied, mythic) memory, something is always lost.

Los recuerdos del porvenir traces the occupation of Ixtepec by General Francisco Rosas following the Mexican revolution, the ongoing abuses by the military in collusion with a local landowner, Rodolfo Goríbar, and the town's eventual participation in the Cristero rebellion of the 1920s. The first half of the novel centers on Rosas's mistress, Julia Andrade, an enigmatic young woman who lives enclosed in the Hotel Jardín along with the mistresses of the other officers. Her flight with a mysterious stranger, Felipe Hurtado, closes the first half of the novel and intensifies the conflict between the 
townspeople and Rosas. The second half of the novel centers on Isabel Moncada, daughter of one of the town's leading families. Isabel contributes to the efforts of the town's elite to outwit Rosas and secure the safe escape of the priest, Padre Beltrán, by distracting the general and his officers with an elaborate party. Afterward, Isabel accepts Rosas's invitation and returns with him to the hotel. Several conspirators, among them Isabel's brother Nicolás, are subsequently tried and executed.

Although it contains concrete references to the violence of the Cristero revolt, Garro's novel also presents a mythical time of long horizons and uncertain duration. If Los recuerdos del porvenir is a historical novel, it is so in the broadest sense of the term, as a novel that is set in an identifiable past. All of the principal characters are fictitious. Yet it is a novel in which history-a particular, concrete, history-is invoked, and as more than a casual gesture of contextualization or temporal grounding. While Part I carries numerous allusions to the Revolution and its various factions and upheavals-it is only as a representative of one of those factions that Rosas is in Ixtepec at allPart II clearly names the conflict between President Calles and the church. Until the Calles Law of 1926, the anticlerical provisions of the Constitution of 1917 (such as the mandating of secular education, outlawing of monastic orders, restrictions on priests, and nationalization of the churches) had been unevenly enforced. The Calles decree mandated the closing of the churches for inventory; churches were then to be turned over to neighborhood committees. Church authorities responded by suspending all worship services, a suspension that remained in effect until the accord reached between church and state in 1929. Tensions culminated in the uprising between 1926 and 1929 of the so-called "cristeros" under the slogan, "Viva Cristo Rey." The insurrection was violently repressed, with massacres of Cristeros and hangings of priests. Although the churches were reopened in 1929 with the formal resolution of the conflict, confrontations continued during the 1930s.

The two mirror halves of the novel- the first centered on Julia, the second on Isabel-place the novel's treatment of the past within a frame of female embodiment. The link between memory and body is inescapable. As Mary Warnock observes in Memory, "I am my body; but my body, including, of course, my brain, carries memory along with it" (73). Amy Kaminsky describes the collective memory of Ixtepec as "embodied and disembodied at the same time" (Reading 81). This embodied/disembodied link-a connection, not a divide-is important. Both Isabel and Julia might be seen in the same light, their motives and actions interpreted through a lens of embodi- 
ment (and misuse of that embodiment) even as they are disembodied, evacuated, or emptied out into the vessels or bearers of metaphorical or mythological meaning. Thus, although their embodiment provides a superficial explanation for their actions and for the events surrounding them, it is ultimately the absence of their bodies that becomes most significant. Physically, Julia's is a genuine absence-she is never seen or heard from againwhile Isabel's is marked by the apparent presence of the rock into which she is transformed. Julia is femininity incarnate, all of its promise (beauty, love, romance) and danger (immorality, seduction, retribution). Rosas's violence is interpreted as compensating for Julia's denied love, her indifference and unreadability. Julia becomes the fairy-tale princess rescued by the knight in shining armor; her body melts into nothing. In contrast, Isabel's transformation fixes forever her isolation and loneliness; her body "ossifies" into stone. Julia and Isabel function as the representatives of a memory that is paradoxically condemned to oblivion as well as repetition. Each presents an accessible surface that nonetheless, with its excess visibility, covers more than it reveals. The deceptive visibility of Isabel Moncada and Julia Andrade rewrites the memory of the town across the solid yet empty spaces marked by their bodies and by the local mythology surrounding their origins and ends.

Julia and Isabel produce the physical space of narrative possibility, but it is a possibility that is undermined from the start by memory's arbitrary reordering of events and the limits of what the town remembers. Isabel's is a presence that consists of a kind of erasure, in the way that monumental or customary objects become invisible through familiarity. Julia's presence is similar, in that although at times highly visible, she is just as often absent, hidden away inside the hotel, and her immortality is achieved through her magical escape. Finally, the description of the disappearance (or transformation) of each requires the intervention of an outside narrator to complete the limited information available to Ixtepec.

Los recuerdos del porvenir presents memory as fluid and unfixed, as temporally unmoored, at once personal and shared, limitless and constrained. Memory encompasses both specific dates and private thoughts. Memory here is collective, although variable in the degree to which it is shared; it is capable of being taken in or assumed by another person. Moreover, memory is necessarily partial, incomplete. As Richard Terdiman points out, "Reduction is the essential precondition for representation. Loss is what makes our memory of the past possible at all" (22). This loss, in the novel, becomes concretely evident in the transformation of Isabel into stone and in the subsequent 
interpretation of that transformation. But loss or reduction are evident as well in the narrator's frequent admission of gaps in its memory. Writing in the context of the aftermath of Argentina's "dirty war" and debates about how to remember and commemorate the disappeared, Elizabeth Jelin stresses that to forget "does not imply a void or a vacuum. It is the presence of the absence, the representation of what was once there and no longer is, the representation of something that has been erased, silenced or denied" ("Minefields" 29). Although Garro's novel is not wholly congruent with recent theories of memory and trauma, certain elements of the narrative structure are reminiscent of descriptions of trauma. According to Jelin, "es la imposibilidad de dar sentido al acontecimiento pasado, la imposibilidad de incorporarlo narrativamente, coexistiendo con su presencia persistente y su manifestación en síntomas, lo que indica la presencia de lo traumático" (Los trabajos 28). What Jelin writes about trauma resonates with the structure of Garro's novel, although the events of the novel do not necessarily, or not entirely, conform to all aspects of the definition of trauma offered by Jenny Edkins, who argues that, to be considered traumatic, an event must combine an experience of powerlessness as well as betrayal, so that "what we call trauma takes place when the very powers that we are convinced will protect us and give us security become our tormenters" (4). Central also to trauma is repetition. As Cathy Caruth explains, "trauma is described as the response to an unexpected or overwhelming violent event or events that are not fully grasped as they occur, but return later in repeated flashbacks, nightmares, and other repetitive phenomena" (91). Repetition is ultimately fundamental to all memory, traumatic or no. Patrick Hutton describes what he terms

[T]wo moments of memory: repetition and recollection. Repetition concerns the presence of the past. It is the moment of memory through which we bear forward images of the past that continue to shape our present understanding in unreflective ways. [. . .] Recollection concerns our present efforts to evoke the past. It is the moment of memory with which we consciously reconstruct images of the past in the selective way that suits the needs of our present situation. $(\mathrm{xx}-\mathrm{xxi})$

Repetition and loss, then, or presence and absence, describe the nature of a memory that can be neither erased nor fully reconstructed. Edkins describes memorials that are, in part, successful at "encircling the event, marking its place without narrating it as part of a linear story or national myth" (17). In 
the evacuated form of Isabel Moncada, we see a monument that attempts to narrate a national myth, but that is unable to do so. She becomes a kind of cenotaph or empty tomb, a marker for one buried elsewhere. Almost inadvertently, in spite of itself, the narrative "encircles" the events described. The function of Isabel as monument might be seen as foreshadowing contemporary debates about suitable forms and processes of memorialization. The stone into which Isabel is transformed does not mark a mass grave or the site of a massacre, but she stands as a memorial to official violence-a memorial, again, that enacts the forgetting, voluntary and involuntary, inherent in all remembrance.

In Garro's novel, memory is also a place, a space to occupy. The novel opens with the narrator's statement, "Aquí estoy, sentado sobre esta piedra aparente. Sólo mi memoria sabe lo que encierra" and leads the reader, through an almost wistful enumeration of the locations to which one army or another has moved the town, to the shuttered home of the Moncada family, where all is silence and oblivion (9). And yet, in memory, "hay un jardín iluminado por el sol, radiante de pájaros, poblado de carreras y de gritos" (11). Thus is the reader drawn into the past and the childhood of Nicolás, Juan, and Isabel Moncada. The narrative voice regularly places itself, both in space and time, and at times the town abandons its seat. The guests' trial begins on October 1, a date forever engraved on the town's memory: “Al decirlo ya no estoy sentado en esta aparente piedra, estoy abajo, entrando despacio en la plaza, en los pasos de mis gentes que desde muy temprano se encaminaron alli' (261). Ixtepec is both subject and site of its recollections: the town relates what happened to it as well as what happened within its geographical confines. There are lapses in the town's memory, limits to its perception or awareness. Memory is a variable and shifting mirror, a keeper of secrets and mysteries. And it is based-seated-on a seeming stone, so that that which seems most evident and visible is immediately called into doubt.

David Lowenthal argues that individual memories depend on the memories of others. Yet by shoring up our own with others' recollections, we change-often imperceptibly_the nature and content of our memories. As Lowenthal notes, "In the process of knitting our own discontinuous recollections into narratives, we revise personal components to fit the collectively remembered past, and gradually cease to distinguish between them" (196). To build a narrative past, then, is to link both personal and public or shared information. As narrator, the voice of Ixtepec emphasizes a collective iden- 
tity, a somewhat flexible "we." The narrative voice is selectively omniscient yet personalized. The people "belong" to the town, which exists apart in some overarching way: "También yo me sorprendí del entusiasmo con que mi gente aceptó la idea de la fiesta para el general Francisco Rosas" (194). In her discussion of Los recuerdos del porvenir, Jean Franco observes that "the choice of this collective protagonist has the advantage of giving voice to all the marginalized elements of Mexico-the old artistocracy, the peasantry (and former supporters of the assassinated revolutionary leader Zapata), the indigenous, and women" (134). However, the collectivity represented is not all-encompassing. It excludes the indigenous population (although not entirely unsympathetically) and focuses instead on the town's elite. Marta Portal points out that the collective narrator "nunca se piensa como ramera o como indio 'descalzo' y ahorcado" and argues that "la gente humilde del pueblo son los grandes ausentes de la memoria del pueblo" (262-63). The authority of the narrator, moreover, is repeatedly undermined, although the limits of its knowledge are not all caused by memory. Lola Goríbar and her son Rodolfo, the town's wealthiest inhabitants and the most brazen beneficiaries of post-revolutionary corruption, remain outside the narrator's "we." Thus, the miserly doña Lola's fear is "un miedo distinto del nuestro" (65). Outsiders also remain beyond the narrator's ken. Unlike Rosas, who is equally an outsider and yet more directly understood, Julia appears only through the understanding of others; the reader has no direct access to her interior world. Felipe Hurtado is another stranger whose private thoughts remain inaccessible to the town.

The harsh geographic isolation of Ixtepec is reproduced in the individual isolation of many of its inhabitants, lost in their own worlds of disordered or stagnant time. Although the novel consists of the future's memories, Ixtepec has no future: the events portrayed are now encircled by the past. From the outset, chronology is presented as unstable or unreliable. Says the narrator, "la memoria contiene todos los tiempos y su orden es imprevisible" (12). The novel is circular, in that everything has already happened and the narrative begins at the end. Terdiman notes that memory "complicates the rationalist segmentation of chronology into 'then' and 'now.' In memory, the time line becomes tangled and folds back on itself" (8). To base a novel in memory is already to have disrupted the chronology the novel might attempt to reproduce. Thus, in Los recuerdos del porvenir, memory is perhaps more an index of recognition or familiarity than an indication of something past. Joanna Bartow describes memory as a "point of contact with, or literal 
repetition of, other moments in the past and future" (5). Kaminsky notes that "memory in Recuerdos is any cognitive movement in time, either forward or backward" (Reading 82). I would argue, however, that the cognitive movement in time must include an awareness of that movement, as well as the consciousness of the past. The awareness of that temporal movement, on the part of both characters and narrator, is central to the force of Garro's text.

Both halves of the novel close with magical events that become central elements in the memory of Ixtepec and its people: the flight of Julia with Felipe Hurtado and the transformation of Isabel into stone. These two events, so important to Ixtepec's identity, also reveal the fissures in that identity because both require the intervention of an outsider to fill the gaps in the narrator's knowledge. Cynthia Duncan argues that "the narrative voice in these instances is re-telling the stories, much as one re-tells a legend" (36). Both events defy rational explanation even as both appear to explain or reveal the nature and actions of the two women who so mystify Ixtepec; both episodes leave many questions unresolved. In outwitting time, Julia evades her body as well. Isabel by contrast is reduced to body. Both women are explained in and through their absence, but the memory of that absence makes them permanently present.

Part I closes with the flight of Julia with Felipe Hurtado. Fleeing just as Rosas and his men are about to capture them, the two are able to escape because time stands still. Night freezes in Ixtepec even as day begins in the surrounding countryside. In this instance the narrator must be replaced by the voice of an outsider, a witness to the events: a mule-driver "contó que en el campo ya estaba amaneciendo y al llegar a las trancas de Cocula se topó con la noche cerrada" (145). Uncertain whether to proceed, he saw a horseman pass, carrying in his arms a woman dressed in pink. The town confirms her identity based on her laughter, her pink dress, and the gold beads around her neck. The two are never heard from again. The silence of suspended time continues even after time again moves forward: the flight of Julia and Felipe Hurtado "nos dejó sin palabras" (149). Ixtepec as narrating witness will be replaced a second time, at the end of the novel, with the transformation of Isabel into stone and the ceding of the explanatory voice to Gregoria's inscription.

Throughout the novel, the link between memory and identity is made clear, yet this link is just as often disrupted. As Lowenthal observes, "Selfcontinuity depends wholly on memory; recalling past experiences links us 
with our earlier selves, however different we may since have become" (197). After he buries his son Juan, Martín Moncada finds he has lost "la memoria de sí mismo, y era un personaje desconocido" (245). When Félix shuts the door behind Martín, "nunca más volvimos a verlo por mis calles" (245). Both present and absent, Martín has left the collective identity that is (or was) Ixtepec: we did not see him on my streets. Unrecognizable to himself, Martín becomes unrecognizable (and unseen) to the town as well. Rosas, in turn, has no memory of his own, but is tormented by Julia's memories, or rather, by what he imagines them to be: "en esos recuerdos ajenos e incompletos encontraba ojos y manos que miraban y tocaban a Julia y la llevaban después a lugares en donde él se perdía buscándola” (77). Memory, for Rosas, becomes his fantasy of another person's past.

The seemingly impossible recollections of things still to come color the entire narrative, the reality (or unreality) in which the characters live. To remember is to repeat, to recognize what has already been foretold. Following the occupation of the church during which she confirms her own solitude, Isabel begins "caminando un porvenir que empezaba a dibujarse en su memoria" (161). Isabel's fate is already written, as is that of her brother Nicolás. At the party she tells her father, "Siempre supe lo que está pasando [...] También lo supo Nicolás [ . . .] Desde niños estamos bailando en este día" (207). In the intimacy of his room, she tells Rosas, "Francisco, tenemos dos memorias [. . .] Yo antes vivía en las dos y ahora sólo vivo en la que me recuerda lo que va a suceder" (253). Isabel has always been set apart, lonely when her brothers leave Ixtepec to work in the mines of Tetela, resentful of the notion that she must be married off like so much cut-rate merchandise: "Yo siempre he estado de sobra" she tells Felipe Hurtado (90). Isabel's loss of her second memory reveals the failure of her attempt-along with her brothers - to break out of the static, predetermined time of Ixtepec.

In this novel, elements of timelessness-all the afternoons are the same, the heat is unbearable, and time almost imperceptible-are juxtaposed to more concrete, everyday images of newspapers and family events. Each evening at nine Félix removes the pendulum from the Moncadas' clock. Once the clock is silenced, the room's inhabitants "se convirtieron en recuerdos de ellos mismos, sin futuro" (19). In memory, they remain suspended in that uneasy past, observed by the remembering narrator. Under the domination of Rosas and the fascination of Julia, violence becomes the only antidote to inevitable repetition and endless waiting: "para romper los días petrificados sólo me quedaba el espejismo ineficaz de la violencia, y la crueldad se ejercía 
con furor sobre las mujeres, los perros callejeros y los indios" (63). Ixtepec places its curiously timeless existence in the context of tragedy: "Como en las tragedias, vivíamos dentro de un tiempo quieto y los personajes sucumbían presos en este instante detenido. Era en vano que hicieran gestos cada vez más sangrientos" (63). The three Moncada siblings are only the most visible of the inhabitants who long to break the stagnation of Ixtepec. Even the military occupation has become one more part of the endless routine, the regular murders expected and assimilated.

Duncan argues that "Garro's technique of filtering a historical novel through memory establishes a point-counterpoint relationship between chronological and psychological perceptions of time, thus offering a more complete and thorough vision of the various ways in which human beings see time" (33). Kaminsky notes that "the narrator frequently invokes other moments in time that are equally available, though less or more remote from the assumed present from which it speaks." She argues that the purpose is "not to situate the moment of the anecdote within a greater historical chronology, but, on the contrary, to flatten out the differences between 'before' and 'after'" (Reading 80). Yet I would contend that while the differences between before and after may be flattened out, a greater historical chronology is not obliterated. The story Ixtepec relates of its own past is both timeless (the story of its creation, its near-magical movement from place to place by occupying forces) and concretely grounded. Moreover, the novel's concern extends beyond specific historical events to the nature and possibility of the representation of the past. As Daniel Balderston writes, "instead of taking the historical record of the Mexican revolution as given, Garro calls it into question at every turn" using the fantastic to "undermine the historicity of her fictional world" (41). There is a constant tension between the timeless quality of the story and concrete references to Mexican history and to particular dates in the (fictional) history of Ixtepec. While the narrator tells us that months passed, that Rosas and his men were replaced with another (interchangeable) set of officers, Gregoria's inscription places Isabel's death on October 5, 1927.

The historical events that were largely background in the first part of the novel become more prominent in Part II, in which the Cristero rebellion is depicted as a smokescreen designed to distract the peasants from their demand for agrarian reform. In Garro's representation, the church, a principal landholder, would have much to gain by displacing the peasants' disquiet onto the anticlerical state. Thus, the narrator proclaims that "las dos faccio- 
nes en el poder se disponían a lanzarse en una lucha que ofrecía la ventaja de distraer al pueblo del único punto que había que oscurecer: la repartición de las tierras" (153). Yet more emphatically, the narrator adds, "entre los porfiristas católicos y los revolucionarios ateos preparaban la tumba del agrarismo" (154). The novel represents the church-state conflict as only apparent or superficial. ${ }^{1}$ For this reason, Garro's reading does not fit neatly into either orthodox views of the Mexican revolution as a uniformly popular uprising or revisionary interpretations of the revolution as a power struggle between elites. ${ }^{2}$ The Moncada, Arrieta, and other elite families sympathize with the murdered agraristas and resent the restrictions on the church. The Moncada children, however, are motivated by their own need for escape (and perhaps their self-destructive destiny). Both church and state are subject to criticism; the conspirators in the town are moved by faith and personal loyalty but also by resentment of the military's incursions and the opportunism of Rodolfo Goríbar and his hired guns.

Land reform is repeatedly invoked as a failed promise of the revolution and an excuse for the abuses and violence of those in power. With the complicity of the occupying troops, Rodolfo Goríbar regularly moves boundary markers and expands his land holdings. One of the book's few named Indians, Ignacio, a rumored agrarista, warns Rodolfo not to move the landmarks again: "Los agraristas dicen que lo van a matar" (66). But it is Ignacio who

1. Jennie Purnell argues that the cristiada was neither a straightforward conflict between church and state nor a

[C] onfrontation between a militantly anticlerical state and a politically and culturally homogenous peasantry. Peasants were deeply divided in their responses to revolutionary state formation. For some communities and factions within communities, the agrarian reform program offered the possibility of reclaiming lost lands, and anticlericalism became a vehicle for displacing despised local authorities. For others, these two policies constituted a threat to community resources, understandings of property rights, and institutions of politico-religious authority. (7)

2. Purnell sums up one of the central debates regarding the Mexican revolution as follows:

Orthodox scholars depict the revolution as a massive and undifferentiated popular rebellion in which the political and economic power of the landed class was destroyed to the benefit of the peasantry at large. Revisionist scholars counter that the revolution was little more than a power struggle between national elites, in which the popular values and aspirations embodied in the Zapatista peasant movement were thoroughly defeated, the revolution thereby constituting little more than the modernization of the Porfiriato (1876-1911). (4)

3. Jean Meyer defines the "agraristas" simply as "the beneficiaries of agrarian reform" (85). Purnell uses the term more restrictively to designate "peasants who gave active political or military support to the state or to individual revolutionary leaders" (197). 
dies, along with four other unnamed victims who are found hanging from the trees on the road to Cocula. Martín Moncada uses his prestige to demand that the bodies be returned and Juan Cariño, accompanied by several of the local prostitutes, goes to the military headquarters to protest the murders. Yet the importance of Ignacio's death quickly recedes: "la figura de Ignacio tal como la veo ahora, colgada de la rama alta de un árbol, rompiendo la luz de la mañana como un rayo de sol estrella la luz adentro de un espejo, se separó de nosotros poco a poco. No volvimos a mentarlo. Después de todo, sólo era un indio menos" (91).

According to Franco, both Julia and Isabel remain outside history. Franco reads the novel as a (failed) attempt to write women into the master narrative of the nation. As Franco notes, the novel "is not altogether a historical novel but rather, like Antigone, it challenges the state's appropriation of meaning" (134). Franco concludes that in Garro's novel, "women do not enter history-only romance. Either they are legends like Julia, the elusive phantom of male desire, or like Isabel they are the undesired surrogates who are not objects of desire but who allow themselves to be seduced by power" (138). But to view Los recuerdos del porvenir as simply an attempt to fit women (as heroines) into the national narrative is insufficient. The structure of the novel, its combination of fantastic, mythic, and historical or realistic elements produces a new national narrative that cannot be reduced to either/ or. Part of the novel's challenge to prevailing national discourse lies in its rejection of a single narrative possibility. Sandra Cypess argues that Isabel's "solidity" may refer to her "permanence, her eternal presence. This presence of woman in relation to narration-since it is the voice of Ixtepec seated on this 'piedra aparente' that directly addresses the reader-is yet another example of the way Garro attempts to provide a space for women in national discourse" (69). This image-woman written into the national discourse as stone bench-suggests the extent to which the feminine is always present, even if denied. Historical information in the novel is presented through a mix of myth and history, both interior and exterior perceptions, and measurements of time. The female body, made monument, becomes a marker of that history, one that purports to explain all. History is written on women's bodies, which are then set up as a lesson to others, although the apparent bodies may by then be empty shells. The novel's call to memory is a recognition of forgetting, of loss. The paradox of the title's "recollections of things to come" goes beyond temporal impossibility, because the future that the novel predicts, in which the narrator seated on the seeming stone describes 
the vanished Ixtepec, consists of an overabundant nothingness, an apparently solid yet ultimately empty mass.

To the extent that the novel is "about" the Cristero rebellion, it is also about the ways in which such historical events allow individuals to express their own motivations. The key moments, moreover, remain out of reach. Of the occupation of churches prior to their closure by church authorities to protest governmental restrictions, the narrator explains, "Los años han pasado y aquella inmensa noche en que velamos a la iglesia se aparece en mi memoria con la claridad de una luciérnaga; también como una luciérnaga se me escapa" (158). Surrounded by the throng that occupies the church, Isabel is suddenly attracted to Rosas's solitude and autonomy. She does not recognize herself in the crowd and wishes she could make the leap to Rosas's side: "quería estar en el mundo de los que están solos" (161). Isabel is moved not by Rosas's expression of a particular policy so much as the lure of sanctioned solitude. This is the power that seduces Isabel: the power to stand apart, selfdefined. That Rosas's interior experience is the antithesis of this autonomous, powerful self only adds to the irony. Isabel is not troubled by the predicament of the priest, insisting, "El que debería salvarlo es su amigo Rodolfito para que le siga bendiciendo las tierras que se roba" (265). Juan and Nicolás see the plot as "la puerta de huida," their opportunity of escape (265). As these statements illustrate, although an overall explanation for the Cristero Wars is proposed, the motivations of individual characters tend to be highly idiosyncratic.

The party for Rosas is not the first use of theatricality in an attempt to alter or evade the reality of Ixtepec. The play rehearsals organized by Felipe Hurtado represent a brief, idyllic interruption of illusion into the routine of Ixtepec, a few short hours in which the Moncada siblings are able to approach the longed-for escape. And yet it is during that rehearsal that Isabel pronounces the words that still resonate in the empty house: “ $¡ M$ Mirame antes de quedar convertida en piedra!" (119). Her words provoke an interruption in her own action on stage- "empezó despacio su respuesta y a la mitad de la frase se detuvo" (119)—as well as a narrative interruption, for the narrator recalls and stresses recollection before finally arriving at the problematic phrase. The narrator muses:

Ahora, después de muchos años, los veo a todos esa noche. A Isabel en mitad del tablado, a Hurtado junto a ella, como aturdido por un recuerdo súbito y doloroso; a Nicolás y a Juan, con los ojos interrogantes y listos 
para entrar en escena; a Conchita sentada entre la madre y la tía de los jóvenes, jugando con un cordelito y esperando ser llamada. Recorro la casa y encuentro en el salón de doña Matilde los lazos de colores, las capas hilvanadas, el manto de Isabel. Vuelvo al pabellón y escucho todavía flotantes las palabras dichas por Isabel y que provocaron su interrupción: ‘Mírame antes de quedar convertida en piedra! [. . .]'

Las palabras de Isabel abrieron una bahía oscura e irremediable. Aún resuenan en el pabellón y ese momento de asombro allí sigue como la premonición de un destino inesperado. (119)

In this recollection of an imperfect telling, of interrupted speech, we see again the tangle of memory, time, and representation. The frozen time of Ixtepec extends into its future: what happened once continues to happen ever after. The red dress of the play is repeated at the party whereby the town hopes to deceive Rosas, and the party is itself a failed attempt to achieve the "illusion" Felipe Hurtado had advocated. The play to be performed is never explicitly identified, yet the rehearsals present an abiding image of Isabel and foreshadow her transformation. ${ }^{4}$ Memory here revolves around Isabel's stone body, even before the transformation is complete. The incompleteness of that transformation-she is all stone, yet she is all memory-reveals the way in which memory undoes the transformation even as it relies on that change for its forward movement, for the ability to tell.

Rosas's seduction of Isabel after the party seems to lie in a single word: "vienes." It is the same word with which Ana Moncada once invited Martín to bed: "Ella, después del nacimiento de Nicolás, había llamado a su marido cada noche: '¿Vienes?' Recordó aquellas noches; endulzaba la voz como Francisco Rosas y llamaba a Martín” (239). She remembers, “con esa misma palabra había llamado Rosas a Isabel y su hija se fue con él" (239). ${ }^{5}$ Ana feels herself to blame for her daughter's wickedness and also betrayed by her daughter’s looks. “¡Qué viva! ¡Qué bonita! ¡Se ve que la hicieron con gusto!” exclaims the midwife at Isabel's birth. Ana is both furious and ashamed:

\footnotetext{
4. Debra Castillo offers a suggestive gloss of the multiple allusions of the play, among them the Diana of Greco-Roman tradition and the Aztec moon goddess, Coyolxauhqui, who attempts to kill her mother, Coatlicue, and is in turn killed by her brother, Huitzilopochtli.

5. Sandra Boschetto reads in this passage a representation of Isabel as a "depository of ancestral and more particularly male sin and guilt" but while Martín, too, sees his daughter as alien or apart, the sin that Isabel is seen as revealing is that of Ana's (female) lust (5).
} 
"Todos sabrían su lujuria gracias a la viveza de su hija. [. . . ] Isabel había venido al mundo a denunciarla" (239). Although appearances are everywhere noted as deceptive, Isabel's face is by its nature revealing of what must be hidden. Her body is both productive and sterile. The vivacity that exposed her mother's sexuality is lost when she is turned to stone, yet that transformation allows her body to act as the (spatial) origin of the narrative. The transformation into stone is the logical end of a female being whose very existence reveals too much.

Rosas's attempt to cement his triumph through the seduction of Isabel backfires. Balderston notes that Isabel shatters the general's orderly world because

$[\mathrm{H}] \mathrm{er}$ (present) body erases from his memory the (absent) body of Julia. [Thus,] she erases Julia's images but at the same time exacerbates her absence. The repetition of the same body, in slightly different forms, is intolerable: one or another of them, or both, must turn out to be simulacrum. (44)

This seems a neat encapsulation of the interpretive dilemma posed by the novel. Isabel's present body in the form of the stone reflects the frustration of the narrative, the effort to resolve the tensions between fantastic and historical, between past and present, spatial time and linear time. Yet it is not a matter of prioritizing one over the other (historical or fantastic, realism or romance); rather, the novel is structured around the impossibility of resolution, an impossibility evident, for instance, in the structure of the text, in which the two mirror halves both reproduce and distort one another. Garro's novel presents a thesis about the Cristero rebellion, shredding the official narrative of a mythic revolution. Yet it also replaces one fairy-tale princess with another, one villainess with another. It is the present, unresolved, and irresolvable body of Isabel that is left at the end, an index of the irreducible multivalence of memory.

On the day of the executions, Gregoria leads Isabel to the Virgin's sanctuary so that she can ask that the image of Rosas be driven from her mind. In a way, she has already been turned to stone: "Isabel estaba en el centro del día como una roca en la mitad del campo" (292). Unaware of Nicolás's role in choosing his own death, Isabel repeats to herself, "Mató a Nicolás, me engañó" (293). When she turns and runs down the hill shouting, "aunque dios me condene quiero ver a Francisco Rosas otra vez" Isabel's motivation 
is ambiguous, and necessarily so (293). It is not clear if she turns back out of desire, rage, a sense of betrayal, or some combination. Kaminsky contends that Isabel's need to see the general again "has less to do with the desire to return to a lover's bed than it does with a desire to confront a murderer" ("Residual" 106). Duncan concludes that it is "fear of the loss of memory" that prompts Isabel's return (50). Margarita León in turn sees a degree of self-affirmation in the event: Isabel is willing to purchase a kind of immortality at any cost, "prefiere inmolarse a sí misma, convertirse en piedra, con tal de no ser ignorada, olvidada, borrada del mito" (132). Within the action of the novel, Isabel's desire is never clearly affirmed or demonstrated. Throughout the novel, Isabel's attraction to Rosas is described in terms of the attraction of the loner, of one apart from the town with which she does not (fully) identify. As Kaminsky argues elsewhere, Isabel's link to Rosas "had to do with neither love nor self-sacrifice but rather was a complex matter of destruction and self-destruction" (Reading 94). Ultimately, Isabel acts out of alienation and anger more than sexual desire. It is not lust that motivates Isabel, but desire for a radical autonomy, for the capacity to stand apart that she sees in Rosas. She does not recognize, perhaps, that at the heart of Rosas's solitude, beyond his real power over the town, is his empty core.

Isabel disappears in a whirlwind; Gregoria finds her, now turned to stone, only after much searching. After a laborious night spent pushing the stone up the hill to lay it at the Virgin's feet, Gregoria "bajó a Ixtepec a contar lo sucedido" (294). As at the end of the first part, when Julia's escape is related by the mule-driver, the informative function is passed to an eye-witness. It bears remembering, however, that Gregoria does not see the actual moment of transformation, and it is only her intuition that identifies a particular stone as Isabel.

Ixtepec is present, in the end, only as reader: "Gregoria le puso una inscripción que ahora leo" (295). Gregoria, assuming the voice of Isabel, has the last word: nothing follows the inscription, which reads:

Soy Isabel Moncada, nacida de Martín Moncada y de Ana Cuétara de Moncada, en el pueblo de Ixtepec el primero de diciembre de 1907. En piedra me convertí el cinco de octubre de 1927 delante de los ojos espantados de Gregoria Juárez. Causé la desdicha de mis padres y la muerte de mis hermanos Juan y Nicolás. Cuando venía a pedirle a la Virgen que me curara del amor que tengo por el general Francisco Rosas que mató a mis hermanos, me arrepentí y preferí el amor del hombre que me perdió y perdió a 
mi familia. Aquí estaré con mi amor a solas como recuerdo del porvenir por los siglos de los siglos. (295)

In keeping with the stone's role as historical marker, the inscription is filled with precise dates, names, and places. It is also filled with errors. Gregoria, sole witness and recorder, is unreliable. As Kaminsky points out, "whenever she appears, Gregoria misinterprets what she sees" ("Residual" 104). Duncan notes that the inscription, the last remaining vestige of the town's written history, "is an ironic comment on the validity of written historical accounts, however, for it is neither impartial, nor objective, nor necessarily true" (39). And yet, the novel offers no alternative. The official version is destabilized, but to the reader is left the work of putting something coherent in its place.

It is thus necessary to read the material on which the text is written, in this case, the petrified body of Isabel. Castillo argues that Isabel's story reveals "a multiply staged and voiced unreadability" (93). Lucía Melgar views Isabel's transformation as a double punishment, one that adds to the fate of being turned to stone (and thereby silenced) the imposition of a limited, single interpretation, and concludes that "esta transformación es comparable a la monumentalización, pétrea y escritural, de los héroes caídos a manos de la historia oficial" (60). To accept Gregoria's interpretation as accurate is to accept that it is only by being frozen as stone-punished-that a woman can enter into language. While Gregoria's perspective is individually marginal, her reading of events seems to correspond to a dominant, patriarchal discourse. Moreover, it is Isabel's failure to leave, to make good her escape, that makes possible the narrative. Nothing replaces the dominant version perhaps because, as with individual memories, the disordered and unreliable tissue of interwoven recollections has no outside, nothing that can take its place.

Isabel has become a stone mirror, the image in which the narrating town finds itself reflected. She has also become text. Boschetto points out that:

[The] transformation of Isabel Moncada's body into sign, language, and text revises the former reading to render a new construction. Keeping in mind that the stone is always and only "aparente" as the narrator consistently refers to it, the writing and rewriting of Garro's text upon an earlier one revises both the old and the new. [Thus,] the undifferentiated memory of the stone between real and unreal, past, present, and future time creates 
a contradictory, suspended temporality, which again appears to annul the petrification of Isabel. (8-9)

Yet the memory relayed is not the memory of the stone, but of Ixtepec, although Ixtepec sees itself in the stone (and, perhaps, sees itself more than it sees Isabel, so that Isabel is again erased, becoming no more than a mirror to the collective past). It is again her present absence-that is, her memorythat makes possible the collective memory. Boschetto argues that "blank, unwritten, the 'stone/text' is complete potentiality" (9). But the stone is not, in fact, unwritten. It is very firmly and permanently (if misleadingly) overwritten by Gregoria's inscription. Isabel is not unwritten, but she is unreadable, because to properly read Isabel herself, rather than Isabel as a distorted representation of Ixtepec, one would have to read what is no longer there. The crucial link between body and memory again becomes evident in the stone monument that preserves the body without its contents: the body as memory, but no memory within it, an empty figure of unresolved loss. The human body, ever perishable and fragile, is transformed into the seemingly eternal stone, yet the individual memory associated with that body is lost forever.

Images of stones recur throughout the novel, so that Isabel's transformation is the culmination not only of her own destiny but of the town's unfolding memory. Isabel is associated with the image of a meteor, a flying stone, both petrified and mobile. Martín sees the danger his wife overlooks: "Isabel podía convertirse en una estrella fugaz, huir y caer en el espacio sin dejar huellas visibles de ella misma" (30). Stones are also linked to mirrors and reflection. Boschetto explains that "the Nahuatl roots of the toponym 'Ixtepec'-itzli (obsidian) and tepetl (hill) are particularly significant when we understand that some pre-Columbian Meso-American necromancers sought visions of the past and the future in obsidian scrying-stones" (11). The town as mirror becomes the future-revealing mirror of the sorcerer, the rock of divination. Thus, Justo Corona and Rosas "miraron a la plaza tendida como un espejo de piedra" (182). Luchi's house, the brothel, has the distorted appearance of a house reflected in a broken mirror, so that its ruined walls "trataban de hacerse muy pequeños, crecían enormes al final de una calle que terminaba en piedras" (57). The image they give back to the town is distorted as well; although the women are not allowed on the main streets, the brothel is the home of the highly ethical and decent Juan Cariño. The prostitutes are cast out of the visible space of the town, yet they play an 
Gladhart : PRESENT A BSENCE 109

important political role-Castillo terms them "below suspicion" (83) accompanying Juan Cariño to claim Ignacio's body in Part I and hiding Padre Beltrán in Part II.

Always, the persistence of memory demands a consciousness of absence. This narrative that is all memory includes a catalog of what has been forgotten, even as the listed recollections seem to contradict the statement of lack:

Si la memoria me devolviera todos los instantes contaría ahora cómo nos retiramos de la plaza y cómo cayó polvo sobre el pan caliente de Agustina y cómo esa tarde no hubo nadie que lo comiera.

Diría también cómo fue la luz de duelo de esa noche y qué formas tuvieron sus árboles violetas, pero no lo recuerdo. (270-71)

This is the longed-for memory in the face of the shock that follows on the trial and its verdicts. But memory cannot return to us every instant. Implied beyond such lists must be the still greater list of details uncataloged and hence utterly forgotten, a forgetting in which the awareness that something has been lost is not available to consciousness.

The tension between presence and absence creates the conditions for a misreading of Isabel, whose (apparent) presence is in fact an absence: she is not there, and her body as text is therefore unreadable. Similarly, her embodiment becomes a disembodiment, as her human, fleshly form is replaced by the static, almost immovable stone. Isabel's petrified body is the mark of what has been forgotten, the "representation of what was once there" that Jelin describes. With its misleading inscription, it is also an attempt to speak to the future, to provoke memory. Only Ixtepec's memory knows what the seeming stone encloses; only Ixtepec remembers what has been forgotten. Isabel, frozen in stone, is a monument of absence, for while she has been unable to escape, neither is she present. The stone contains no adequate explanation of her actions. The words inscribed upon it are misleading, their attribution to Isabel patently false. "Yo sólo soy memoria," the narrator states at the beginning, and memory, as ever, is an index of the irrecuperable past. Yet in its transformation into text, the body, in all its messy corporeal presence, is never fully pushed aside. Because this double figure of presence and absence, remembering and forgetting lies at the center of the narrative, there can be no entirely satisfying closure. The novel is imperfectly resolved, leaving the reader unsettled. As narrator, the town of Ixtepec rests on a seem- 
ing stone, but it is not really a stone, and the town-displaced, reformed, erased, forgotten-is not truly at rest. ${ }^{6}$

\section{Works Cited}

Balderston, Daniel. “The New Historical Novel: History and Fantasy in Los recuerdos del porvenir." Bulletin of Hispanic Studies 66 (1989): 41-46.

Bartow, Joanna R. "Isolation and Madness: Collective Memory and Women in Los recuerdos del porvenir and Pedro Páramo." Revista Canadiense de Estudios Hispánicos 18.1 (1993): 1-15.

Boschetto, Sandra. "Romancing the Stone in Elena Garro's Los recuerdos del porvenir." Journal of the Midwest Modern Language Association 22.2 (1989): 1-11.

Caruth, Cathy. Unclaimed Experience: Trauma, Narrative, and History. Baltimore: Johns Hopkins UP, 1996.

Castillo, Debra A. Easy Women: Sex and Gender in Modern Mexican Fiction. Minneapolis: U of Minnesota P, 1998.

Cypess, Sandra Messinger. "Dis(re)membered Bodies and Temporal Games in the Texts of Elena Garro." Studies in Honor of Myron Lichtblau. Ed. Fernando Burgos. Newark, DE: Juan de la Cuesta, 2000. 65-78.

Duncan, Cynthia. “Time and Memory as Structural Unifiers in Elena Garro's Los recuerdos del porvenir." Journal of Interdisciplinary Literary Studies/Cuadernos Interdisciplinarios de Estudios Literarios 4.1-2 (1992): 31-53.

Edkins, Jenny. Trauma and the Memory of Politics. Cambridge: Cambridge UP, 2003.

Franco, Jean. Plotting Women: Gender and Representation in Mexico. New York: Columbia UP, 1989.

Garro, Elena. Los recuerdos del porvenir. México: Joaquín Mortiz, 1963.

Hutton, Patrick H. History as an Art of Memory. Hanover, NH: UP of New England; Burlington, VT: U of Vermont P, 1993.

Jelin, Elizabeth. "The Minefields of Memory." NACLA Report on the Americas 32.2 (1998): 23-29.

- Los trabajos de la memoria. Madrid: Siglo XXI de España, 2002.

Kaminsky, Amy K. Reading the Body Politic: Feminist Criticism and Latin American Women Writers. Minneapolis: U of Minnesota P, 1993.

—. "Residual Authority and Gendered Resistance." Critical Theory, Cultural Politics, and Latin American Narrative. Ed. Steven M. Bell, Albert H. Le May, and Leonard Orr. Notre Dame: U of Notre Dame P, 1993. 103-21.

6. This article was written with the generous support of a Faculty Research Fellowship from the Oregon Humanities Center. Shorter versions were presented at Brigham Young University and at the Western Humanities Alliance conference held at the University of Utah, October, 2003. 
Gladhart : PRESENT A BSENCE 111

León, Margarita. "Las voces femeninas en el umbral de la conciencia: las heroínas en la obra de Elena Garro." La palabra y el hombre 113 (2000): 127-33.

Lowenthal, David. The Past is a Foreign Country. Cambridge: Cambridge UP, 1985.

Melgar, Lucía. "Relectura desde la piedra: ambigüedad, violencia y género en Los recuerdos del porvenir de Elena Garro." Pensamiento y crítica: los discursos de la cultura hoy. Ed. Javier Durán, Rosaura Hernández Monroy, and Manuel F. Medina. East Lansing: Michigan State University/Centro de Cultura Casa Lamm, 2000. 58-74.

Meyer, Jean A. The Cristero Rebellion: The Mexican People Between Church and State, 1926-1929. Trans. Richard Southern. Cambridge: Cambridge UP, 1976.

Portal, Marta. Proceso narrativo de la revolución mexicana. Madrid: Espasa-Calpe, 1980.

Purnell, Jennie. Popular Movements and State Formation in Revolutionary Mexico: The Agraristas and Cristeros of Michoacán. Durham: Duke UP, 1999.

Terdiman, Richard. Present Past: Modernity and the Memory Crisis. Ithaca: Cornell UP, 1993.

Warnock, Mary. Memory. London: Faber and Faber, 1987. 
Copyright of Hispanic Review is the property of Hispanic Review and its content may not be copied or emailed to multiple sites or posted to a listserv without the copyright holder's express written permission. However, users may print, download, or email articles for individual use. 